\title{
Analysis of the Nutritional Composition of Aquatic Species Toward Nutritional Improvement in a Lao PDR Rural Area
}

\author{
Kaori FUJITA ${ }^{1 *}$, Masataka SAITO ${ }^{2}$, Bounsong VONGVICHITH ${ }^{3}$, \\ Katsumi HASADA ${ }^{1}$, Philavanh BOUTSAVATH ${ }^{4}$, \\ Xaypunya MAHATHILATH ${ }^{4}$ and Shinsuke MORIOKA ${ }^{1}$ \\ ${ }^{1}$ Japan International Research Center for Agricultural Sciences (Tsukuba, Ibaraki 305-8686, Japan) \\ ${ }^{2}$ Laboratory of Food Science and Technology, Kagawa Nutrition University (Sakado, Saitama 350- \\ 0288, Japan) \\ ${ }^{3}$ Living Aquatic Resources Research Center (LARReC) (Sikhottabong District, Vientiane, Lao \\ PDR) \\ ${ }^{4}$ Planning and Cooperation Division, National Agriculture and Forestry Research Institute (NAFRI), \\ Ministry of Agriculture and Forestry (Xaythany District, Vientiane, Lao PDR)
}

\begin{abstract}
Nine species of fish (Clarias batrachus, Clarias microcephalus, Anabas testudineus, Henicorhynchus siamensis, Puntius brevis, Rasbora aurotaenia, Channa striata, Channa gachua, and Esomus metallicus) and three types of shellfish (Viviparidae spp., Pomacea spp., and Unionidae spp.) available in Nameuang Village and in the capital city Vientiane of Lao People's Democratic Republic were analyzed in terms of nutritional composition to investigate their value as food resources with the aim of improving the nutritional status in rural areas of the country. A total of 35 types of fish and shellfish were consumed in the surveyed village. Some species of fish had a high protein content (19-20 g/100 g sample) and quality (e.g., lysine content $=1,750-1,870 \mathrm{mg} / \mathrm{g}$ sample and $93.8-97.9 \mathrm{mg} / \mathrm{g}$ protein). Their protein qualities were endorsed by amino acid score (amino acid score 100). These results suggest that the analyzed aquatic animals have high nutrient quality and are efficient/ indispensable food resources for improving the nutritional status of the rural population of the country.
\end{abstract}

Discipline: Food

Additional key words: aquatic animals, fish and shellfish, nutritional value, Lao People's Democratic Republic, rural area

\section{Introduction}

The Lao People's Democratic Republic (PDR) is still classified as one of the least developed countries in the world. In this country, malnutrition is a nationwide problem, causing the following situations: $34 \%$ of the children under the age of 5 years is underweight and more than half of the children $(63 \%)$ are stunted in terms of growth (UNICEF 2012). It is reported that the catch-up growth of children can be enhanced via the intake of food with the protein and energy levels suited to the child's age (WHO/FAO/UNU 2007). Furthermore, FAO (2013b) summarized that $11.0 \%$ of households with poor and limited food consumption, and $26.7 \%$ of undernourished in the total population. The above situations are considered to be due to insufficient animal protein intake resulting from the limited supply of animal protein sources (FAOSTAT 2018). This often causes overdependency on rice in deprived areas (MAF 2013), particularly in semi-mountainous rural areas where access to animal proteins is more limited in quality and quantity than in urban areas (Hasada \& Yamada 2017).

Lao PDR is largely dependent on inland freshwater products, including fish and shellfish, for nutritional supply (Phonvisay 2013, Halwart \& Bartley 2014). The national policy for improvement of malnutrition in rural areas is to increase the animal protein supply, including aquatic products by means of fishery/aquaculture

*Corresponding author: e-mail fujitak@affrc.go.jp

Received 19 October 2018; accepted 27 December 2018. 
promotion. Moreover, along with the increase in aquatic production, preparation of information on the nutritional values of such aquatic animals is also necessary as a public awareness for nutritional improvement. However, there is little information about the nutritional value of the typical diet in rural areas of Lao PDR. Although food composition databases of other countries are present (ASEAN Food Composition Database [FCD] 2014), these mainly include large and well-known types of fish or shellfish consumed and do not reflect the species that are consumed by residents of Lao PDR. In addition, the data are derived from a large number of sources including regional databases with variable sampling and analytical methods, with the sample size unclear in some cases. However, information on the nutrients in actual aquatic species consumed in rural areas of Lao PDR is essential for improving the nutritional status of the population. In the present study, therefore, we analyzed the essential nutritional compositions and protein qualities of the major aquatic animals consumed in rural areas of Lao PDR in order to prepare their actual nutritional information, which will contribute to the improvement of the nutritional status in these areas.

\section{Materials and methods}

\section{Survey site}

The survey site was Nameuang Village, Feuang District, Vientiane Province (Fig. 1). This village was

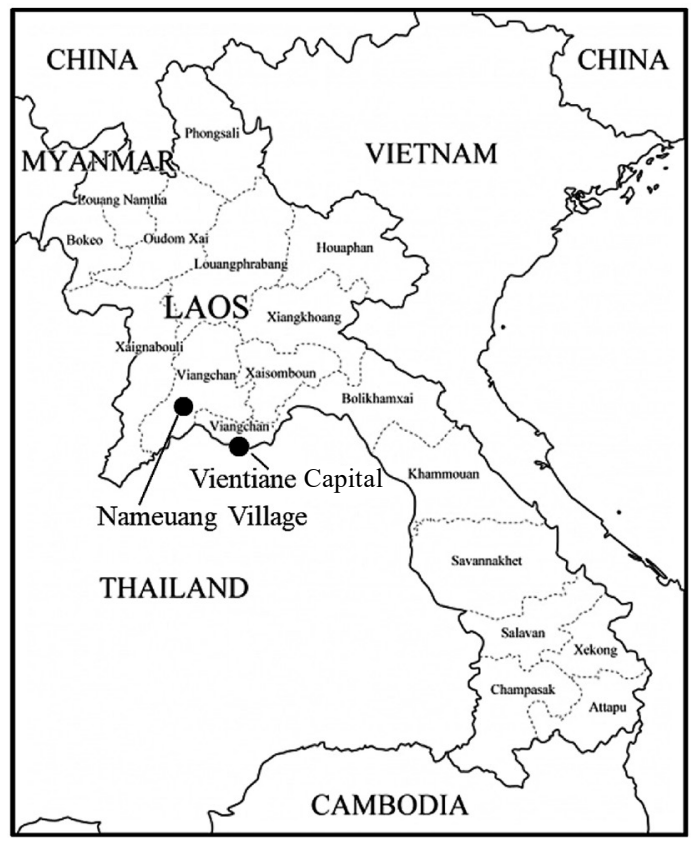

Fig. 1. Location of the survey sites in Lao PDR (Fujita et al.) (a map modified from "Asia Laos Map - Laos maps," Mapsof.net, http://mapsof.net/laos/asia-laos-map) selected since it is a typical village in the mountainous area of central Vientiane Province mainly inhabited by rice farmers. The demographic profile of the village has been previously reported (Ikeura et al. 2016); the population size and number of households in the village are 683 and 135, respectively. Paddy fields are distributed in lowland fields (81 ha) and in mountainous areas (12 ha).

\section{Methods of sample selection}

The species were selected from a list of fish and shellfish based on an interview with the village chief (Table 1). The list was edited to include data from previous surveys of food consumption in the village (Hasada 2014) and from two reports on the diversity of freshwater animals of the Mekong river basin (NEF 2015, Poulsen et al. 2004). Table 1 shows the results of the interview with the village chief conducted in June 2015, which included information on the types of fish and shellfish that are regularly consumed by the villagers. The samples for nutritional analysis were selected from Table 1 based on the following criteria: they constitute a major part of the diet, are frequently consumed (yearround), and are the preferred food of most of the villagers. Thus, five groups of fish (Pa duk, Pa keng, Pa khao, Pa kor, and $\mathrm{Pa}$ siew) and three types of shellfish (Hoy chup, Hoy pakkuang, and Hoy kii) were selected.

\section{Sampling and identification}

Sampling was conducted in a village and two domestic markets from Nameuang Village and Vientiane, the capital of Lao PDR, during December 2-8, 2015. The size of the samples depended on the activities of the individuals supplying the village. NaNga market $\left(18^{\circ} 13^{\prime} 59.9^{\prime \prime} \mathrm{N}, \quad 102^{\circ} 29^{\prime} 21.4^{\prime \prime} \mathrm{E}\right)$ in the north and Dongmakkhay market $\left(18^{\circ} 04^{\prime} 55.4^{\prime \prime} \mathrm{N}, 02^{\circ} 40^{\prime} 14.4^{\prime \prime} \mathrm{E}\right)$ in the mid-eastern part of the Vientiane Capital were selected owing to the abundance of natural fish and shellfish traded directly between the villagers and the traders rather than through a hub market. Samples from the two markets were investigated by questioning the sellers to ensure that their origins differed. In the village, the sample collection was dependent on the activities of the villagers. In total, 39 fish and shellfish samples were collected from Vientiane and Nameuang Village. The number of samples varied for each species but was approximately $1 \mathrm{~kg}$ (on a wet weight basis) for each pooled sample from the market. In the village, it was difficult to collect large amounts of a single pooled sample, and approximately $400 \mathrm{~g}$ was therefore used for the analysis.

Detailed information on each species, including the 
common names in the local language and the scientific names, is shown in Table 1. We sampled two species of the walking catfish, Pa duk-i.e., Pa duk en (Clarias batrachus) and Pa duk oui (Clarias macrocephalus)since they are widely consumed in the country. Regarding the swamp barb ( $\mathrm{Pa}$ khao), at least three genera (five species) were available from the market, but only three species (swamp barb A, B, and C) were analyzed since there was insufficient material available for the other two. Two species of snakehead, Pa kor (Channa striata and Channa gachua), were also evaluated.

Table 1. Current consumption status of fishes and shellfishes in the village

\begin{tabular}{|c|c|c|c|c|}
\hline No. & Lao name & English name & Scientific name & Availability* \\
\hline \multicolumn{5}{|l|}{ Fishes } \\
\hline 1 & Pa duk en & Walking catfish & Clarias batrachus & ++ \\
\hline 2 & Pa duk oui & Bighead catfish & Clarias macrocephalus & ++ \\
\hline 3 & Pa eed & Hasselt's loach & Lepidocephalichthys hasselti & + \\
\hline 4 & Pa gadaeng & Beardless barb & Cycloheilichthys apogon & ++ \\
\hline 5 & Pa gadeud & Tree spotted gourami & Trichogaster trichopterus & ++ \\
\hline 6 & Pa kaa & Malayan leaffish & Pristolepis fasciata & ++ \\
\hline 7 & Pa karbkong & Glass perch & Parambassis siamensis & ++ \\
\hline 8 & Pa keng & Climbing perch & Anabas testudineus & ++ \\
\hline 9 & Pa khang & Bonylip barb & Osteochilus vitattus & ++ \\
\hline 10 & Pa khao & Swamp barb & Barbodes aurotaeniatus & ++ \\
\hline 11 & Pa khao & Swamp barb & Puntius brevis & ++ \\
\hline 12 & Pa khao & Swamp barb & Puntius stoliczkanus & - \\
\hline 13 & Pa khao & Javaen barb & Systomus rubripinnis & ++ \\
\hline 14 & Pa kor & Snakehead & Channa striata & +++ \\
\hline 15 & Pa kor kan & Dwarf snakehead & Channa gachua & ++ \\
\hline 16 & Pa kot & & Hemibagrus filamentus & ++ \\
\hline 17 & Pa lard & Tire track eel & Mastacembelus favus & ++ \\
\hline 18 & Pa lod & Peacock eel & Macrognathus siamensis & ++ \\
\hline 19 & Pa nai & Common carp & Cyprinus carpio & ++ \\
\hline 20 & Pa nil & Nile tilapia & Oreochromis niloticus & ++ \\
\hline 21 & Pa pak & Silver barb & Barbonymus gonionotus & ++ \\
\hline 22 & Pa seuam, Pa khoun & & Ompok miostoma & ++ \\
\hline 23 & $\mathrm{~Pa}$ siew, $\mathrm{Pa}$ gasiew & Flying barb & Esomus metallicus & ++ \\
\hline 24 & $\mathrm{~Pa}$ siew, $\mathrm{Pa}$ gasiew & Cherry spot rasbora & Rasbora rubrodorsalis & ++ \\
\hline 25 & Pa siew, Pa gasiew & Black line rasbora & Rasbora borapetensis & ++ \\
\hline 26 & $\mathrm{~Pa}$ siew, Pa gasiew & Sidestripe rasbora & Rasbora paviei & - \\
\hline 27 & Pa sotong & Needlefish, Freshwater garfish & Xenentodon cancila & ++ \\
\hline 28 & Pa sood & Hampala barb & Hampala macrolepidota & ++ \\
\hline 29 & Pa sood & Eye-spot barb & Hampala dispar & ++ \\
\hline 30 & Pa tong & Bronze featherback & Notopterus notopterus & ++ \\
\hline \multicolumn{5}{|c|}{ Snails and Clams } \\
\hline 31 & Hoy pakkouang & Apple snail & Pomacea spp. & +++ \\
\hline 32 & Hoy po & Apple snail & Pila sp. & ++ \\
\hline 33 & Hoy pan & Apple snail & Pila sp. & ++ \\
\hline 34 & Hoy choup & River snail & Viviparidae spp. & +++ \\
\hline 35 & Hoy lekchan & River snail & Broia spp. & + \\
\hline 36 & Hoy kii & Margaritiferidae (Freshwater bivalve) & Unionidae spp. & +++ \\
\hline 37 & Hoy kii noy & Asian clam (Freshwater bivalve) & Corbicula sp. & + \\
\hline
\end{tabular}

* Availability was estimated based on the village chief comments, ++: commonly available, + : occasionally available, $-:$ not available. 


\section{Sample pre-treatment}

Fresh or live samples were collected and packed in plastic bags at the collection site, and transported with ice to the Living Aquatic Resources Research Center on the same day. Thereafter, the samples were stored frozen at $-30^{\circ} \mathrm{C}$. The frozen samples were transported to the Japan International Research Center for Agricultural Sciences, Tsukuba, Ibaraki, Japan, for nutrient composition analysis.

The edible parts of fish may or may not include the head, internal organs (viscera), scales, bones, and other parts according to traditional practices and depending on the species. The edible parts of the snails also differed with the species. Fillets with skin were analyzed in all kinds of fish without small size fish. i.e., flying barb (Pa siew, Esomus metallicus) and swamp barb C (Pa khao, Rasbora aurotaenia). These two kinds of fish were analyzed using whole-fish body. Clam (Hoy kii, Unionidae spp.) was used for analysis without shell, and the snails were prepared as follows: the river snail (Hoy chup, Viviparidae spp.) was used after removal of the shell and its juveniles inside if they were present, whereas the apple snail (Hoy pakkuang, Pomacea spp.) was used after removal of the shell and internal organs (viscera). The length, height, and weight of the frozen samples were measured using the method of NEF (2015) (Fig. 2). After dissecting the samples, the edible fractions were calculated with the following formula:

$$
\begin{aligned}
& \text { Edible fraction }(\%) \\
& =\frac{\text { total weight of edible part }(g)}{\text { total weight of sample }(g)} \times 100
\end{aligned}
$$

The samples were homogenized and subsamples of the homogenate were used for individual analytical tests.

\section{Analytical methods}

(1) Proximate composition

Essential food properties such as moisture, protein, fat, carbohydrates, and ash contents were evaluated according to the Standard Tables of Food Composition in Japan (STFCJ) (2015) based on the Association of Official Agricultural Chemists methods (Table 2). Each measurement was carried out in duplicate.

The protein content was analyzed using the Kjeldahl method and the quantity was calculated as 6.25 times the $\mathrm{N}$ content. The energy was calculated using the Atwater's coefficient as a conversion factor: 4 for proteins and carbohydrates and 9 for fat. The total carbohydrate was calculated by subtracting measured moisture, protein, fat and ash from total weight as content was calculated from the total weight of each of the other components with the following formula:

$$
\begin{aligned}
& \text { Carbohydrate }(g / 100 g) \\
& =100-(\text { total moisture }(g / 100 g)+\text { protein }(g / 100 g) \\
& + \text { fat }(g / 100 g)+\text { ash }(g / 100 g))
\end{aligned}
$$

\section{(2) Amino acid analysis}

The amino acid composition of each sample was determined according to STFCJ (2015) using an automated amino acid analyzer (JLC-500/V; JEOL, Tokyo, Japan) except for tryptophan, which was detected by HPLC with a RF-20Axs spectrofluorometric detector (Shimadzu). The contribution of each species to the recommended nutrient intake of amino acids at each age was determined by comparisons to reference data. The amino acid score determines the effectiveness with which absorbed dietary $\mathrm{N}$ can meet the essential amino acid requirement at a safe level of protein intake, and is based on the amount of the limiting amino acid in $1 \mathrm{~g}$ of protein in a sample relative to the required amount $(\mathrm{FAO} / \mathrm{WHO} /$ UNU 2007) using the following formula:

$$
\begin{aligned}
& \text { Amino acid score } \\
& =\frac{m g \text { of amino acid in } 1 g \text { test protein }}{m g \text { of amino acid requirement pattern }} \times 100
\end{aligned}
$$
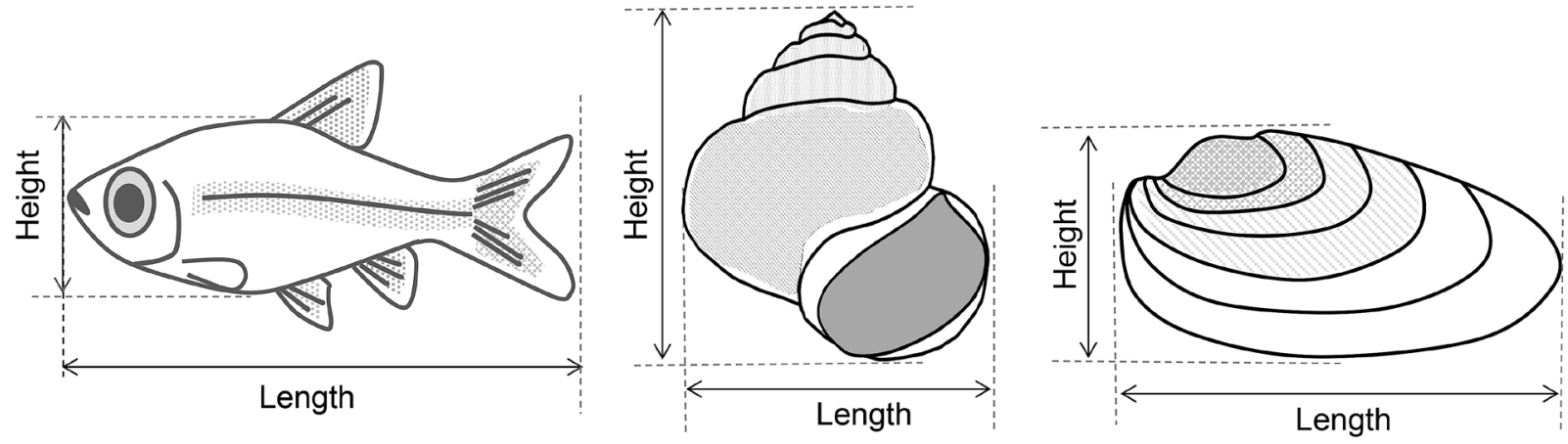

Fig. 2. Length and height in fish, snail, and clam 


\section{Results and discussion}

\section{Fish and shellfish in Nameuang Village}

The people of Nameuang Village depend on aquatic animals for nutrition (Kimura et al. 2014), as in other rural areas of Lao PDR (Funge-Smith 2014, Halwart \& Bartley 2014). Approximately $79 \%$ of the total animal protein intake by weight for the villagers is reported to be from fish and shellfish (note that data regarding birds and reptiles are not available), and that 33 types of fish and shellfish are consumed in the village, making these the second most diverse animal food resources next to insects (Kimura et al. 2014).

Through the course of our interview, we determined that some species of fish were not consumed or not available in the village, but that a total of 35 types of fish and shellfish were regularly consumed (Table 1). Although this represents a smaller variety than in Attapeu province (61, 95, and 102 species of fish in the Tamoyot, Gayeu, and Sausa Villages, respectively; FAO 2003), aquatic animals are clearly an indispensable food resource in Nameuang.

\section{Size and weight of the fish and shellfish in Nameuang Village}

There were no differences in the length of the samples collected at the two locations (Table 3). The edible fraction of almost all fish species was over $43 \%$, except for climbing perch (Anabas testudineus), which has hard and heavy head, bones, and scales and thus have fewer edible parts than other fish. The edible fractions of swamp barb $\mathrm{C}$ ( $R$. aurotaenia) and flying barb ( $E$. metallicus) were considered to be $100 \%$ (w/w) since in both cases the whole fish is regularly consumed according to the interview in the village.

The edible fractions of apple snails (Pomacea spp.) and river snails (Viviparidae spp.) totaled around 30\%, while Margaritiferidae (Unionidae spp.) had a higher proportion of edible parts $(>52 \%)$. The lower fraction of edible parts in apple snail was due to the removal of the large viscera from the body per the dietary custom of the village. The main reasons for the low proportion in river snails are the hard and heavy shell and the fact that this organism is ovoviviparous; the removal of the embryos from the body shells of a pregnant snail prior to consumption of the latter decreases its edibility value. However, edibility rates of livestock animals in Japan are $35-55 \%$ and vary according to cultural and dietary practices, condition of the livestock, or status of the breeding lines. Others have reported edibility rates of $40-55 \%$ in livestock (van Huis et al. 2013). The rates in freshwater animals do not differ significantly from those in marine fish (STFCJ 2015).

\section{Proximate composition}

The proximate food composition, including crude protein, fat, carbohydrate, ash, moisture and energy content of the edible parts of the 12 species of nine fishes and three shellfishes are shown in Table 4. Although most residents of Nameuang Village consume apple snail without the viscera, in other studies reporting on the nutritional value of these animals it is unclear whether the analyses were performed with or without the viscera (Baby et al. 2010, Nurhasan et al. 2010). We, therefore, investigated the viscera separately so that we could compare our results with previous data.

Table 2. Analytical methods used for determining nutrient composition

\begin{tabular}{|c|c|c|c|c|}
\hline Analyzed items & Unit & Method & Sample weight (g) & $\mathrm{LOQ}^{*}$ \\
\hline \multicolumn{5}{|l|}{ Proximate composition } \\
\hline Energy & $\mathrm{g} / 100 \mathrm{~g}$ & Calculation & & \\
\hline Moisture & $\mathrm{g} / 100 \mathrm{~g}$ & Air oven method & $1.0-4.0$ & $0.1 \mathrm{~g} / 100 \mathrm{~g}$ \\
\hline Protein & $\mathrm{g} / 100 \mathrm{~g}$ & Kjedahl method & $0.7-3.0$ & $0.1 \mathrm{~g} / 100 \mathrm{~g}$ \\
\hline Fat & $\mathrm{g} / 100 \mathrm{~g}$ & Soxlet extraction method & $1.0-5.0$ & $0.1 \mathrm{~g} / 100 \mathrm{~g}$ \\
\hline Carbohydrate & $\mathrm{g} / 100 \mathrm{~g}$ & Calculation & & \\
\hline Ash & $\mathrm{g} / 100 \mathrm{~g}$ & & & \\
\hline \multicolumn{5}{|l|}{ Amino acid } \\
\hline Amino acid (17 kinds) ${ }^{* *}$ & $\mathrm{~g} / 100 \mathrm{~g}$ & Amino acid analyzer method & $0.5-1.0$ & $0.1 \mathrm{mg} / 100 \mathrm{~g}$ \\
\hline Amino acid (Tryptophan) & $\mathrm{g} / 100 \mathrm{~g}$ & HPLC & $1.0-2.0$ & $0.1 \mathrm{mg} / 100 \mathrm{~g}$ \\
\hline
\end{tabular}

\footnotetext{
* LOQ: Limit of quantitation

** 17 kinds of amino acids: Histidine, Isoleucine, Leucine, Lysine, Methionine, Cysteine, Phenylalanine, Tyrosine, Threonine, Valine, Arginine, Alanine, Glycine, Proline, Glutamic acid, Asparagine, Serine
} 
The total protein content in the fish species ranged from 19-20 g/100 g, except in swamp barb A and flying barb. The latter had the lowest content among all fish, but this was assumed to be because all parts of the fish such as the head, bones, and viscera were included in the analysis. On the other hand, the protein contents in the three types of shellfish ranged from 7.8-12.3 g/100 g, with no significant differences among the species. It is well known that the main food elements of aquatic animals are moisture and protein; the values measured in this study were within the ranges previously reported in ASEAN FCD (2014), Nurhasan et al. (2010) and STFCJ (2015).

Climbing perch and members of the family Cyprinidae (three swamp barbs and flying barb) had lower water and protein contents, and had also higher fat content $(2.5-10.1 \mathrm{~g} / 100 \mathrm{~g})$ than the other species (e.g., catfish, 0.3-2.4 g/100 g; snakehead, 0.4-0.5 g/100 g; and shellfish, 0.5-0.9 g/100 g). This is in accordance with previous data obtained for fish species in Lao (Nurhasan et al. 2010), although others have reported a two to seven times higher fat content in these fish than that observed in the present study (James 2006, ASEAN FCD 2014).
Although the reason for these discrepancies is unclear, most of these data were from fishes in Thailand, Cambodia, and Vietnam, and those might have been cultured fishes that were considered to have more fat than the wild fishes used in this study.

The total energy content varied widely among species from 79-168 kcal/100 g, which was mainly due to differences in fat content. In general, the carbohydrate content is low in fish and high in shellfish (STFCJ 2015). We observed the same trend in fish $(0.0$ to $1.1 \mathrm{~g} / 100 \mathrm{~g})$ and shellfish (2.6-10.0 g/100 g) in this study, but dwarf snakehead had a high value $3.2 \mathrm{~g} / 100 \mathrm{~g}$. All shellfish and two fish species (swamp barb C and flying barb) had a high ash content ranging from 1.8 to $4.9 \mathrm{~g} / 100 \mathrm{~g}$ and 4.0 to $5.1 \mathrm{~g} / 100 \mathrm{~g}$, respectively. The high amount of ash in the two fish species can be explained by the fact that the viscera, bones, and head were included in the measurement. Similarly, the high ash content of shellfish (river snail and Margaritiferidae members) was likely due to the inclusion of the viscera during the pre-treatment for the proximate analysis.

Table 5. Amino acid compositions in fish, snail and clam

\begin{tabular}{|c|c|c|c|c|c|c|c|c|c|c|c|c|c|c|}
\hline \multirow{2}{*}{ Sample name } & \multicolumn{2}{|c|}{ Walking catfish } & \multicolumn{2}{|c|}{$\begin{array}{c}\text { Climbing } \\
\text { perch }\end{array}$} & \multicolumn{2}{|c|}{ Snakehead } & \multicolumn{2}{|c|}{ Flying barb } & \multicolumn{2}{|c|}{ River snail } & \multicolumn{2}{|c|}{ Apple snail } & \multicolumn{2}{|c|}{ Margaritiferidae } \\
\hline & $\mathrm{mg} / \mathrm{g}^{*}$ & $\mathrm{mg} / 100 \mathrm{~g} * *$ & $\mathrm{mg} / \mathrm{g}$ & $\mathrm{mg} / 100 \mathrm{~g}$ & $\mathrm{mg} / \mathrm{g}$ & $\mathrm{mg} / 100 \mathrm{~g}$ & $\mathrm{mg} / \mathrm{g}$ & $\mathrm{mg} / 100 \mathrm{~g}$ & $\mathrm{mg} / \mathrm{g}$ & $\mathrm{mg} / 100 \mathrm{~g}$ & $\mathrm{mg} / \mathrm{g}$ & $\mathrm{mg} / 100 \mathrm{~g}$ & $\mathrm{mg} / \mathrm{g}$ & $\mathrm{mg} / 100 \mathrm{~g}$ \\
\hline Histidine & 22.5 & 430 & 23.4 & 450 & 24.6 & 480 & 28.6 & 460 & 22.9 & 220 & 18.4 & 210 & 20.5 & 180 \\
\hline Isoleucine & 46.1 & 880 & 42.2 & 810 & 44.1 & 860 & 41.0 & 660 & 38.5 & 370 & 38.6 & 440 & 43.2 & 380 \\
\hline Leucine & 83.2 & 1,590 & 78.6 & 1,510 & 80.5 & 1,570 & 74.5 & 1,200 & 76.0 & 730 & 80.7 & 920 & 76.1 & 670 \\
\hline Lysine & 97.9 & 1,870 & 91.1 & 1,750 & 93.8 & 1,830 & 82.6 & 1,330 & 60.4 & 580 & 59.6 & 680 & 76.1 & 670 \\
\hline Methionine & 29.8 & 570 & 28.6 & 550 & 30.3 & 590 & 26.7 & 430 & 19.8 & 190 & 17.5 & 200 & 25.0 & 220 \\
\hline Cysteine & 9.9 & 190 & 9.9 & 190 & 10.3 & 200 & 9.3 & 150 & 12.5 & 120 & 10.5 & 120 & 12.5 & 110 \\
\hline Phenylalanine & 44.0 & 840 & 43.2 & 830 & 43.1 & 840 & 41.0 & 660 & 40.6 & 390 & 37.7 & 430 & 37.5 & 330 \\
\hline Tyrosine & 34.0 & 650 & 31.8 & 610 & 33.8 & 660 & 31.7 & 510 & 34.4 & 330 & 32.5 & 370 & 34.1 & 300 \\
\hline Threonine & 49.2 & 940 & 45.3 & 870 & 45.1 & 880 & 41.6 & 670 & 46.9 & 450 & 44.7 & 510 & 45.5 & 400 \\
\hline Tryptophan & 9.9 & 190 & 9.9 & 190 & 10.3 & 200 & 9.3 & 150 & 12.5 & 120 & 10.5 & 120 & 11.4 & 100 \\
\hline Valine & 50.3 & 960 & 47.4 & 910 & 47.2 & 920 & 45.3 & 730 & 46.9 & 450 & 45.6 & 520 & 46.6 & 410 \\
\hline Arginine & 67.5 & 1,290 & 65.6 & 1,260 & 64.1 & 1,250 & 61.5 & 990 & 76.0 & 730 & 85.1 & 970 & 72.7 & 640 \\
\hline Alanine & 66.0 & 1,260 & 69.3 & 1,330 & 64.6 & 1,260 & 65.8 & 1,060 & 55.2 & 530 & 61.4 & 700 & 51.1 & 450 \\
\hline Glycine & 73.3 & 1,400 & 74.0 & 1,420 & 60.5 & 1,180 & 70.8 & 1,140 & 60.4 & 580 & 70.2 & 800 & 46.6 & 410 \\
\hline Proline & 44.0 & 840 & 44.8 & 860 & 38.5 & 750 & 44.7 & 720 & 45.8 & 440 & 49.1 & 560 & 35.2 & 310 \\
\hline Glutamic acid & 162.0 & 3,090 & 152.0 & 2,920 & 156.0 & 3,040 & 144.0 & 2,320 & 145.0 & 1,390 & 161.0 & 1,830 & 145.0 & 1,280 \\
\hline Aspartic acid & 109.0 & 2,090 & 103.0 & 1,970 & 104.0 & 2,030 & 96.3 & 1,550 & 105.0 & 1,010 & 103.0 & 1,170 & 95.5 & 840 \\
\hline Serine & 43.5 & 830 & 41.7 & 800 & 42.1 & 820 & 39.8 & 640 & 45.8 & 440 & 47.4 & 540 & 47.7 & 420 \\
\hline
\end{tabular}

* mg/g protein

** $\mathrm{mg} / 100 \mathrm{~g}$ sample 


\section{Amino acids}

Protein quality can be predicted basically based on the indispensable amino acid score from a comparison of the pattern of its amino acid composition to the pattern of human amino acid requirement (FAO 2013a). In the present study, it was not possible to evaluate the digestibility of protein. The amino acid compositions of each sample are shown in Table 5. The two most abundant amino acids, i.e., glutamic acid and asparagine, were the same across samples. The third and fourth most abundant amino acids (lysine and leucine) were the same in all fish samples, whereas in shellfish the third and fourth were leucine and arginine in the river snail, arginine in the apple snail, and leucine and lysine in the Margaritiferidae. The glutamic acid content was also high (2,920-3,090 $\mathrm{mg} / 100 \mathrm{~g}$ and $152-162 \mathrm{mg} / \mathrm{g}$ ) in fishes, except in swamp barb $(2,320 \mathrm{mg} / 100 \mathrm{~g}$ and $144 \mathrm{mg} / \mathrm{g})$. These observations differ not only from previously reported values (Nurhasan et. al. 2010) but also from those of common sea fish (STFCJ 2015), as the amino acid content is generally species-specific. Overall, the glutamic acid content of shellfish was not very high $(1,280-1,390 \mathrm{mg} / 100 \mathrm{~g}$ and $145 \mathrm{mg} / \mathrm{g})$, except in the apple snail $(1,830 \mathrm{mg} / 100 \mathrm{~g})$, for which the content in $1 \mathrm{~g}$ of protein $(162 \mathrm{mg} / \mathrm{g})$ was almost the same as the highest value in all the fishes (walking catfish, $161 \mathrm{mg} / \mathrm{g}$ ).

Lysine is an essential amino acid. Especially in rural areas of Asia there is predominance of rice farming and consumption, which causes a deficiency of this amino acid in the diet (Vasal, 2002). In this study, the lysine content of fish $(1,330-1,870 \mathrm{mg} / 100 \mathrm{~g}$ and $82.6-97.9 \mathrm{mg} / \mathrm{g})$ was higher than that of shellfish $(580-680 \mathrm{mg} / 100 \mathrm{~g}, 59.6-$ $76.1 \mathrm{mg} / \mathrm{g})$. Notably, the lysine contents of walking catfish and snakehead $(1,870 \mathrm{mg} / 100 \mathrm{~g}$ and $97.9 \mathrm{mg}$, and 1,830 $\mathrm{mg} / 100 \mathrm{~g}$ and $93.8 \mathrm{mg} / \mathrm{g}$, respectively) were higher than the previously reported values $(1,503 \mathrm{mg} / 100 \mathrm{~g}$ and 79.1 $\mathrm{mg} / \mathrm{g}$, and $1,493 \mathrm{mg} / 100 \mathrm{~g}$ and $80.3 \mathrm{mg} / 100 \mathrm{~g}$, respectively) in Nurhasan et al. (2010). The lysine contents in fish and shellfish are higher than in livestock animal proteins such as fillet of lean meat of beef $(90-95 \mathrm{mg} / \mathrm{g})$, rib roast lean meat of beef $(88-91 \mathrm{mg} / \mathrm{g})$, fillet lean meat of pork $(87$ $\mathrm{mg} / \mathrm{g}$ ), and roast lean meat of pork $(89 \mathrm{mg} / \mathrm{g}$ ) (STFCJ 2015).

The amino acid scores were calculated for each age category based on the new amino acid scoring pattern (WHO/FAO/UNU 2007). The analyzed fish and shellfish samples of the present study were rich in essential amino acids and showed a good balance of protein in all categories for each age with appropriate amino acid scores (>100), particularly for children from the age of 1 to 18 years. As previously mentioned, lysine is a critical component of the typical diet in rural Asia where milled rice - which is low in lysine, a limiting amino acid in protein synthesis - is the staple food (STFCJ 2015). Thus, the aquatic animals consumed by the people of Nameuang Village can potentially prevent malnutrition.

\section{Conclusions}

The purpose of this study was to evaluate the nutrient composition of fish and shellfish species consumed in Lao PDR with a specific focus on rural areas. The results here demonstrate that the aquatic animals analyzed here, in particular fish such as the walking catfish, climbing parch, and snakehead, had high protein contents and quality with appropriate amino acid scores. These types of fish also had especially high lysine contents. Although their supply amount in rural areas is currently considered insufficient (Hasada \& Yamada 2017), and increase of their supply through fishery/ aquaculture promotion may contribute to reduce the malnutrition status (UNICEF 2012) that is caused by protein deficiency (Vongvichith et al. 2018). Moreover, because of these freshwater fish and shellfish species are widely consumed in inland area of the world, these data can also be useful from a nutritional public health standpoint for improving the nutritional status in rural areas not only in Lao PDR but widely in other developing countries and areas.

\section{Acknowledgments}

The authors thank the National Agriculture and Forestry Research Institute and the Living Aquatic Resources Research Center of Lao PDR for the technical assistance and support in surveying the village and Vientiane capital; and Dr. Kouichi Shibukawa, Museum of Natural and Environmental History, Shizuoka, Japan, for assistance in identifying fish species. Research activities for this study were funded by the Japan International Research Center for Agricultural Sciences, Japan.

\section{References}

ASEAN Food Composition Database (2014) ASEAN Food Composition Database. ASEANFOODS Regional Center and INFOODS Regional Database Center, Institute of Nutrition, Mahidol University, Nakhon Pathom.

Baby, R.L. et al. (2010) Nutrient analysis of some commercially important molluscs of Bangladesh. J Sci Res, 2, 390-396.

FAOSTAT (2018) Country profiles: Lao People's Democratic Republic. http://www.fao.org/faostat/en/\#country/120.

Food and Agriculture Organization (FAO) (2003) The role and nutritional value of aquatic resources in the livelihoods of 
rural people, a participatory assessment in Attapeu Province. Regional Office for Asia and the Pacific of FAO, Bangkok.

Food and Agriculture Organization (FAO) (2013a) Dietary protein quality evaluation in human nutrition. Food and Nutrition Paper 92, FAO, Rome.

Food and Agriculture Organization (FAO) (2013b) Statistics: Food security indicators. Available at https://www. fantaproject.org/sites/default/files/download/LaosNutrition-Profile-Apr2014.pdf.

Funge-Smith, S. (2014) Small scale rural aquaculture in Lao PDR. Provincial Aquaculture Development Project 2014. http://lad.nafri.org.la/show_record.php?mfn=3950.

Halwart, M. \& Bartley, D. (2014) Aquatic biodiversity in ricebased ecosystems. Studies and reports from Indonesia, Lao PDR and the Philippines. FAO, Rome.

Hasada, K. (2014) Utilization of diverse bioresources and its significance for household livelihood in a semimountainous village of central Laos: a preliminary survey on fish resources in watersides. In Symposium abstracts of the Japanese Society of Regional and Agricultural Development Spring 2014, Japanese Society of Regional and Agricultural Development, 53-54 [In Japanese].

Hasada, K. \& Yamada, R. (2017) Current status and issue on food access in a semi-mountainous village of Central Laos. J Jpn Soc Irrig Drain Rural Devel, 85, 469-474 [In Japanese with English summary].

Ikeura, H. et al. (2016) Factors affecting differences in the rainy season rice yield in a lowland area of a mountainous village in Lao PDR. Paddy Wat Environ, 14, 343-353.

James, D.G. (2006) The impact of aquatic biodiversity on the nutrition of rice farming households in the Mekong Basin: consumption and composition of aquatic resources. $J$ Food Composition Anal, 19, 756-757.

Kimura, K. et al. (2014) The economic evaluation on the nontimber forest products collected in the rural areas in central Laos - case study on N Village in Fuang District, Vientiane Prefecture -. Environ Inform Sci, 28, 55-58 [In Japanese with English summary].
Ministry of Agriculture and Forestry (MAF) (2013) Lao P.D.R.: Risk and vulnerability survey 2012/2013. Analysis Report, Vientiane.

Ministry of Education, Culture, Sports, Science and Technology, Japan. Standard tables of food composition in Japan (STFCJ, $7^{\text {th }}$ revised version) (2015) http://www. mext.go.jp/en/policy/science_technology/policy/title01/ detail01/1374030.htm.

Nagao Natural Environment Foundation (NEF) (2015) Mizube no Sachi, Gift of Waterfront (2016 Revised version); Illustrated handbook of edible plants and animals indigenous to the Mekong River Basin. http://www. nagaofoundation.or.jp/e/publication/index.html.

Nurhasan, M. et al. (2010) Nutritional composition of aquatic species in Laotian rice field ecosystems. $J$ Food Composition Anal, 23, 205-213.

Phonvisay, S. (2013) An introduction to the fisheries of Lao PDR, Mekong Development Series No.6. Mekong River Commission, Phnom Penh.

Poulsen, A.F. et al. (2004) Distribution and ecology of some important riverine species of the Mekong River Basin. Mekong River Commission, Phnom Penh.

United Nations Children's Fund (UNICEF) (2012) Lao PDR social indicator survey 2011-12, UNICEF, New York.

van Huis, A. et al. (2013) Edible insects: future prospects for food and feed security. FAO Forestry Paper 171, FAO, Rome.

Vasal, S.K. (2002) The role of high lysine cereals in animal and human nutrition in Asia. In Protein Sources for the Animal Feed Industry, Expert Consultation and Workshop. FAO, Rome, 167-183.

Vongvichith, B. et al. (2018) Factors influencing fish productivity in rice paddy: a case study in Vientiane Province, Central Laos. JARQ, 52, 359-366.

World Health Organization and Food and Agriculture Organization and United Nations University (WHO/FAO/ UNU) (2007) Protein and amino acid requirements in human nutrition 2007. WHO Technical Report Series, 935, WHO, Geneva. 